\title{
Business Policies and New Firm Birth Rates Internationally
}

\author{
John R. Nofsinger ${ }^{1} \&$ Blerina Reca ${ }^{2}$ \\ ${ }^{1}$ College of Business and Public Policy, University of Alaska Anchorage, Anchorage, Alaska, USA \\ ${ }^{2}$ College of Business and Innovation, University of Toledo, Toledo, Ohio, USA \\ Correspondence: John R. Nofsinger, Seward Endowed Chair in Finance, College of Business and Public Policy, \\ University of Alaska Anchorage, Anchorage, AK, 99508-4614, USA. Tel: 1-907-786-4148. E-mail: \\ john.nofsinger@uaa.alaska.edu
}

Received: August 14, 2014

Accepted: August 28, 2014

Online Published: September 2, 2014

doi:10.5430/afr.v3n4p1

URL: http://dx.doi.org/10.5430/afr.v3n4p1

\begin{abstract}
The creation of new businesses is vitally important to a healthy economy. Governments can enact laws and enforcement policies to foster and protect business. Or, the priority in some countries can be to protect employees and labor organizations. We examine how the business policies and laws enacted foster or inhibit new firm births in 19 countries. Firm birth rates are analyzed in countries with various business polices and control for legal environments, quality of government, and cultural variables. We conclude that policies which inhibit large firm competitiveness also foster more new firm births. Policies that give large firms an advantage seem to restrain firm births. High accounting standards favor the specialization ability of large firms and reduce new firm startups. Firm death rates are also examined.
\end{abstract}

Keywords: Business policies, Quality of government, Legal environment, Startups

\section{Introduction}

Entrepreneurship plays an important function in an economy. Specifically, new firm creation is associated with the creation of employment (Demirguc-Kunt, Klapper, \& Panols, 2013; Fritsch, 2008), economic growth (Klapper, Love, \& Randall, 2014; Foster, Haltiwanger, \& Krizan, 2006; Wong, Ho, \& Autio, 2005), and the commercialization of high-quality innovations (Lowe \& Ziedonis, 2006). Praag and Versloot (2007) describe how a higher number of start-ups is associated with higher levels of employment rates in these new firms themselves. An increase in employment means more income, which leads to a higher demand for goods and services. Therefore, a high rate of start-ups lead to higher economic growth that benefits all parts of the economy. Also, young firms grow proportionately faster than older, larger firms tend to grow.

Studies of firm birth rates tend to focus on a time series in a single country or region within a country. The literature examines birth rates in United States (Reynolds, Miller, \& Maki, 1995; Zucker, Darby, \& Brewer, 1998), the United Kingdom (Anyadike-Danes, Hart, \& O'Reilly, 2005), India (Audretsch, Boente, \& Tamvada, 2007), and Italy (Santarelli \& Piergiovanni, 1995), to name a few. However, few studies conduct cross-country analysis of business creation. The variation in laws between regions (or over time) in a country are likely to be small compared to the cross-country variations. Nofsinger and Wang (2011) demonstrate this large cross-country variation in examining entrepreneurial access to external capital and find that legal and cultural influences have a strong impact on the type and source of capital acquisition — an important aspect of new firm births.

Therefore, we study how various government business policies influence the creation of new firms in 19 countries. Countries periodically change their laws and regulations. Sometimes laws favor businesses and at other times they favor consumers (Nofsinger, 2012). But there are often a specific set of regulations that are very important for business (Armour \& Cumming, 2006). The tenor of the laws that regulate investors and business can contribute or inhibit the country's economic success. However, these laws and regulations are typically designed to either protect workers (see Botero, Djankov, La Porta, López-de-Silanes, \& Shleifer, 2004) from the power of large, existing companies, or to protect the capital providers and business owners (La Porta, López-de-Silanes, Shleifer, \& Vishny, 1998). Laws protecting labor and laws protecting businesses often conflict. Much has been written about the consequences of this conflict with regard to finance (see for example, La Porta, López-de-Silanes, Shleifer, \& Vishny, 1997; Beck, Demirgüç, \& Maksimovic, 2005; Nofsinger, 2012). Klapper, Laeven, and Rajan (2006) and 
Klapper, Amit, Guillén, and Quesada (2008) show that the legal environment and government quality impact the incentives and ability for entrepreneurs to start new businesses in Europe and around the world. Thus, we control for legal environment and government quality in our analysis.

The potential conflict between business owners and labor in policy formation is typically discussed in the context of existing large companies. Many of the policies for protecting labor involve labor unions and thus do not apply to small firms and startups. In this regard, we form our general hypothesis: policies that inhibit large company competitiveness will lead to economic inefficiencies that can be exploited by new, small firms. In short, what is bad for big business may be good for entrepreneurs. Our hypothesis is operationalized through the examination of firm birth rates.

The startup of new businesses requires substantial capital and time. In the early stages of the process, there are start-up expenses that might seem large compared to the firm's capital base. Specifically, there is a great deal of government and legal paperwork that needs to be completed before a new business opens (Djankov, La Porta, López-de-Silanes, \& Shleifer, 2002). Employers also must pay taxes covering worker's compensation insurance and unemployment benefits. This is especially difficult because new businesses have limited resources and staff. This is where regulations can help encourage or discourage entrepreneurs in starting new businesses. Governments can help by easing the process of getting credit or loans, or by exempting small businesses from certain regulations, like filing specific taxes or legal paperwork.

There are also legal barriers to business activity (Beck et al., 2005). For example, legal frameworks that include labor laws, employment dispute rules, minimum wage, discrimination rules, vacation, child labor laws, family, medical, women in the workplace, etc., have been created to protect employees. Regulations that protect workers may also make large firms inefficient and provide a comparative advantage to small firms.

There are also regulations that protect businesses (La Porta, López-de-Silanes, Shleifer, \& Vishny, 2000; Djankov, Ganser, McLiesh, Ramalho, \& Shliefer, 2008) and promote economic activity. For example, property rights protection is associated with higher economic growth (Claessens \& Laeven, 2003; Johnson, McMillan, \& Woodruff, 2002), as are laws enhancing the development of the financial sector (Rajan \& Zingales, 2003). Reducing legal barriers has the potential for improving economic efficiency. A good example comes from Guasch and Hahn (1999). They estimate an approximate welfare gain of $\$ 35$ billion to $\$ 46$ billion (1990 dollars) a year from eliminating entry and exit restrictions and freeing prices to market levels in the United States. Such innovations increased productivity and reduced operating costs in the range of one-fourth to more than one-half in some industries.

Our procedure is straightforward. First, we introduce our business policy variables of the Employment Law Index, Collective Relations Index, Social Security Law Index, Accounting Quality Index, the Regulation of Entry Index, and the corporate income tax rate. Then we introduce control variables for the legal system, quality of government, and culture. For the legal system, we include the role of legal origin, the efficiency of the judicial system, the rule of law, and three legal environment indexes; eviction procedure, collection of checks and credit rights. The quality of government characteristics include corruption and repudiation risk. Lastly, we include the role of culture through language and religion. We add the cost of bankruptcy to the death rate analysis.

The next section presents our firm birth rate data and the variables of interest. Section III presents the empirical finding for the determinants of the firm birth rates. Section IV extends the analysis to firm death rates across countries. We conclude in section V.

\section{Data}

We examine the annual business birth rate in countries around the world. The birth rate is the ratio of new businesses started during the year to the total number of businesses already operating. The annual birth rates of new businesses are obtained from the OECD / Eurostat Business Demography Database and cover the period from year 1995 to 2007. The data for years 2008 to 2011 are from Entrepreneurship Indicators Programme. Only the enterprises with at least one employee at the start-up are considered, guaranteeing that only true "businesses" are counted. The original sample included 30 countries. However, some of our independent variables are not available for all countries and thus we must limit the analysis to 19 countries for a total of 195 observations. (Note 1)

In Table 1 we report sample statistics by year for the birth rate and death rate and three important economic variables (private credit, the Gross Domestic Product (GDP) and unemployment rate). Private credit measures the credit issued to the private sector as opposed to credit issued to governments and public enterprises. The observations are few in the first few years and then more stable through 2011. The mean for the birth rate varies from 0.088 for the years 2009 and 2010 to 0.122 for the year 1995 . 
Table 1. Sample Statistics

\begin{tabular}{|c|c|c|c|c|c|c|c|c|c|c|c|c|c|c|c|c|c|}
\hline & 1995 & 1996 & 1997 & 1998 & 1999 & 2000 & 2001 & 2002 & 2003 & 2004 & 2005 & 2006 & 2007 & 2008 & 2009 & 2010 & 2011 \\
\hline Countries & 3 & 4 & 4 & 13 & 13 & 14 & 15 & 13 & 8 & 13 & 11 & 12 & 9 & 11 & 12 & 12 & 12 \\
\hline Birth Rate mean & 0.122 & 0.107 & 0.107 & 0.100 & 0.095 & 0.106 & 0.100 & 0.095 & 0.113 & 0.096 & 0.108 & 0.106 & 0.103 & 0.092 & 0.088 & 0.088 & 0.089 \\
\hline St. Dev. & 0.068 & 0.061 & 0.059 & 0.033 & 0.031 & 0.047 & 0.030 & 0.027 & 0.031 & 0.024 & 0.020 & 0.029 & 0.030 & 0.030 & 0.026 & 0.023 & 0.023 \\
\hline Countries & 3 & 3 & 10 & 13 & 13 & 12 & 10 & 7 & 10 & 8 & 10 & 9 & 4 & 10 & 12 & 12 & 11 \\
\hline Death Rate mean & 0.092 & 0.104 & 0.086 & 0.077 & 0.081 & 0.086 & 0.090 & 0.095 & 0.090 & 0.094 & 0.089 & 0.086 & 0.071 & 0.077 & 0.081 & 0.081 & 0.087 \\
\hline St. Dev. & 0.057 & 0.044 & 0.025 & 0.028 & 0.025 & 0.037 & 0.045 & 0.040 & 0.034 & 0.025 & 0.027 & 0.038 & 0.047 & 0.032 & 0.034 & 0.035 & 0.055 \\
\hline Private Credit mean & 1.189 & 1.332 & 0.955 & 1.028 & 1.022 & 0.972 & 1.094 & 1.101 & 1.160 & 1.217 & 1.202 & 1.239 & 1.282 & 1.283 & 1.386 & 1.384 & 1.381 \\
\hline St. Dev. & 0.310 & 0.482 & 0.490 & 0.535 & 0.548 & 0.305 & 0.333 & 0.344 & 0.349 & 0.351 & 0.340 & 0.383 & 0.377 & 0.404 & 0.476 & 0.483 & 0.475 \\
\hline GDP Growth mean & 1.625 & 2.422 & 3.344 & 3.013 & 3.178 & 4.022 & 1.721 & 2.046 & 1.558 & 3.008 & 2.478 & 3.105 & 3.200 & 0.399 & -4.282 & 2.214 & 1.510 \\
\hline St. Dev. & 0.900 & 1.225 & 1.451 & 1.840 & 1.508 & 0.608 & 0.578 & 1.375 & 1.698 & 0.944 & 0.919 & 0.920 & 1.117 & 0.883 & 1.840 & 1.738 & 1.381 \\
\hline Unemployment mean & 5.200 & 5.475 & 8.836 & 7.313 & 6.936 & 6.343 & 5.563 & 7.054 & 6.608 & 6.677 & 6.418 & 6.008 & 6.011 & 6.318 & 7.842 & 8.425 & 8.333 \\
\hline St. Dev. & 2.200 & 2.445 & 5.107 & 4.343 & 3.699 & 3.281 & 2.350 & 2.216 & 2.013 & 2.108 & 1.857 & 1.923 & 1.882 & 2.534 & 3.861 & 4.292 & 4.941 \\
\hline
\end{tabular}

This table reports mean Firm Birth Rates, Firm Death Rates, Private Credit, GDP Growth, and Unemployment Rate. Our sample size includes 19 countries, with 179 observations for the firm birth rate and 157 observations for the firm death rate. The annual birth rates and death rates of new businesses for the period 1995 through 2011 are obtained from the OECD / Eurostat Business Demography Database and the Entrepreneurship Indicators Programme. Private credit and GDP Growth is from International Monetary Fund and Unemployment from LABORSTA, Labour Statistics Database.

Table 2 presents brief definitions and sources of all the variables used. The first section discusses the firm birth and death rates. The second section describes six business policy variables. These variables are the main focus of this paper and are chosen because they are laws and policies that the government could change. First, the ease of doing business in a country (The World Bank, 2007) may affect firm birth rates. We find this index very useful because it ranks economies by the business regulations from the following 10 topics: (1) Starting a business; (2) Employing workers; (3) Dealing with licenses; (4) Registering property; (5) Paying taxes; (6) Protecting investors; (7) Enforcing contracts; (8) Trading across borders; (9) Getting credit; (10) Closing a business. A low ranking means that the government has created a regulatory environment conducive to operating a business. We examine this index to test if the business regulatory environment provided by the government does actually encourage the creation of new businesses. To examine the effect of labor regulations on birth rates we include these three measurements: employment laws index, collective relations laws index, and social security laws index (Botero, et al., 2004). Lower scores for these measurements mean lower levels of protection for workers. Strict labor laws may make running a firm more difficult, and thus provide disincentives for starting a business. We also include a rating on accounting standards (La Porta et al., 1998). The sixth business variable is the statutory corporate tax rate (Djankov, Ganser, McLiesh, Ramalho, \& Shleifer, 2010). This the highest marginal corporate income tax rate combined for all levels of government. Djankov et al. (2010) shows that high tax rates lead to lower economic activity. The highest marginal tax rates are mostly relevant to the largest firms. This could create an opportunity for small firms operating at lower tax rates, which would give them a lower after-tax cost of capital. 
Table 2. Description of Variables

\begin{tabular}{|c|c|}
\hline Variable Name & Description \\
\hline & Dependent Variables \\
\hline Birth rate & $\begin{array}{l}\text { Rate of new start-ups firms. It is calculated by dividing the number of new enterprises with at least one } \\
\text { employee by the population of all active enterprises with at least one employee. Source: The data for the } \\
1995 \text { to } 2007 \text { period are from OECD / Eurostat Business Demography Database, while the post-2007 } \\
\text { data are from Eurostat. }\end{array}$ \\
\hline \multirow[t]{2}{*}{ Death rate } & $\begin{array}{l}\text { Number of firm deaths in one year divided by the total number of active enterprises with at least one } \\
\text { employee in the previous period. Source: The data for the } 1995 \text { to } 2003 \text { period are from OECD / } \\
\text { Eurostat Business Demography Database, while the } 2004 \text { to } 2011 \text { data are from preliminary EIP data. }\end{array}$ \\
\hline & Policy Variables \\
\hline $\begin{array}{l}\text { Rating on } \\
\text { Accounting } \\
\text { Standards }\end{array}$ & $\begin{array}{l}\text { The Index measures the quality of each country's accounting system. It is created by examining and } \\
\text { rating the country's companies' } 1990 \text { annual reports on their inclusion or omission of } 90 \text { items. These } \\
\text { items fall into seven categories (accounting standards, income statements, balance sheets, funds flow } \\
\text { statement, stock data, general information, and special items). We rescaled the variable from } 0 \text { to } 10 \text {, } \\
\text { from previous scale of } 1 \text { to } 100 \text { with lower scores for lower quality. Source: La Porta et al., } 1998 \text {. }\end{array}$ \\
\hline $\begin{array}{l}\text { The ease of doing } \\
\text { business index } \\
\text { (Regulation of } \\
\text { Entry) }\end{array}$ & $\begin{array}{l}\text { Economies are ranked by their business regulations. It is calculated as a simple average of country } \\
\text { percentile rankings on each of the } 10 \text { topics: (1) Registering property; (2) Dealing with licenses; (3) } \\
\text { Employing workers; (4) Starting a business; (5) Getting credit; (6) Enforcing contracts; (7) Paying taxes; } \\
\text { (8) Trading across borders; (9) Protecting investors; (10) Closing a business. Rescaled to 0 to 10, from a } \\
\text { previous rank from } 1 \text { - 181. A high ranking means that the government has created a regulatory } \\
\text { environment conducive to operating a business. Source: The World Bank and the International Finance } \\
\text { Corporation, } 2007 .\end{array}$ \\
\hline $\begin{array}{l}\text { Employment laws } \\
\text { index }\end{array}$ & $\begin{array}{l}\text { Measures the protection of employment and labor laws as the average of (1) Dismissal procedures, (2) } \\
\text { Cost of increasing hours worked, (3) Alternative employment contracts, and (4) Cost of firing workers. } \\
\text { We rescale the index to a range of } 0 \text { to } 10 \text {, from a previous rank from } 0 \text { to } 1 \text {. Lower score means lower } \\
\text { protection of labor and employment laws for the country. Source: Botero et al., } 2004 \text {. }\end{array}$ \\
\hline $\begin{array}{l}\text { Collective } \\
\text { relations laws } \\
\text { index }\end{array}$ & $\begin{array}{l}\text { Measures the protection of collective relations laws as the average of (1) Collective disputes, and (2) } \\
\text { Labor union power. Rescaled to } 0 \text { to } 10 \text {, from a previous rank from } 0 \text { to } 1 \text {. Lower score means lower } \\
\text { protection of collective relations laws for the country. Source: Botero et al., } 2004 \text {. }\end{array}$ \\
\hline $\begin{array}{l}\text { Social Security } \\
\text { laws index }\end{array}$ & $\begin{array}{l}\text { Measures social security benefits as the average of (1) Unemployment benefits, and death benefits, (2) } \\
\text { Sickness and health benefits, and (3) Old-age, disability. Rescaled to } 0 \text { to } 10 \text {, from a previous rank from } \\
0 \text { to 1. Lower score means lower social security benefits for the country. Source: Botero et al., } 2004 \text {. }\end{array}$ \\
\hline \multirow[t]{2}{*}{$\begin{array}{l}\text { Statutory } \\
\text { Corporate } \\
\text { Income Tax Rate }\end{array}$} & $\begin{array}{l}\text { The marginal tax rate a company has to pay, assuming that it is in the highest tax bracket, taking into } \\
\text { account federal, state, and local rates. Rescaled to } 0 \text { to } 10 \text { from the previous scale of } 0 \text { to } 100 \text {; with lower } \\
\text { score indicating lower tax rates. Source: Djankov et al., } 2010\end{array}$ \\
\hline & Control Variables \\
\hline Legal origin & $\begin{array}{l}\text { Identifies the legal origin of company law or commercial code of each country. There are five legal } \\
\text { origins: (1) English common law; (2) German commercial law; (3) Scandinavian commercial law; (4) } \\
\text { French commercial law; (5) Socialist/Communist law. Source: La Porta, López-de-Silanes, Shleifer, \& } \\
\text { Vishny, 1999. }\end{array}$ \\
\hline $\begin{array}{l}\text { Legal System } \\
\text { Index }\end{array}$ & $\begin{array}{l}\text { We construct this composite index by combining together the Efficiency of Judicial System, Creditor } \\
\text { Rights, Rule of Law, Eviction Procedures, and Check Collection variables. First we rescale all the } \\
\text { variables between } 0 \text { and } 10 \text {. Then we sum these sub-indices by assigning equal weights to compute an } \\
\text { average. Lower scores indicate lower quality. }\end{array}$ \\
\hline $\begin{array}{l}\text { Efficiency of } \\
\text { Judicial System }\end{array}$ & $\begin{array}{l}\text { Assessment of the efficiency and integrity of the legal environment as it affects business, particularly } \\
\text { foreign firms. It may be taken to represent investors' assessments of conditions in the country in } \\
\text { question. Scaled from } 0 \text { to } 10 \text {; with lower scores indicating lower efficiency levels. Source: La Porta et } \\
\text { al., } 1998 \text {. }\end{array}$ \\
\hline & $\begin{array}{l}\text { and order tradition in the country. Scaled from zero to } 10 \text {, with lower scores for } \\
\text { d order. Source: La Porta et al., } 1998 \text {. }\end{array}$ \\
\hline
\end{tabular}


It measures the legal rights of creditors against defaulting debtors in different jurisdictions. The creditor rights index measures four powers of secured lenders in bankruptcy. (1) The ability of secured creditors to seize their collateral after the petition for reorganization is approved. (2) The existence of creditor Creditor rights consent when a debtor files for reorganization. (3) If secured creditors are paid first out of the proceeds of liquidating a bankrupt firm. (4) If an administrator, and not management, is responsible for running the business during the reorganization. Rescaled to 0 to 10 from previous rank from 0 to 1 ; with lower scores indicating poor creditor rights. Source: Djankov, McLiesh, \& Shleifer, 2007.

\begin{tabular}{|c|c|}
\hline $\begin{array}{l}\text { Formalism index } \\
\text { (1) Check } \\
\text { Collection } \\
\text { (2) Eviction } \\
\text { Procedures }\end{array}$ & $\begin{array}{l}\text { It measures substantive and procedural statutory intervention in judicial cases at lower-level civil trial } \\
\text { courts, and is formed by adding up the following indices: (i) legal justification, (ii) written versus oral } \\
\text { elements, (iii) professionals versus laymen, (iv) engagement formalities, (v) control of superior review, } \\
\text { (vi) statutory regulation of evidence, and (vii) independent procedural actions. Rescaled to } 0 \text { to } 10 \text { from } \\
\text { previous range from } 0 \text { to } 7 \text {; with higher scores indicating higher level of control or intervention in the } \\
\text { judicial process. Source: Djankov, La Porta, López-de-Silanes, \& Shleifer, 2003. }\end{array}$ \\
\hline $\begin{array}{l}\text { Government } \\
\text { Efficiency Index }\end{array}$ & $\begin{array}{l}\text { This composite index is a combination of the Corruption and Risk of Contract Repudiation sub-indices. } \\
\text { We sum these variables that are already scaled from } 0 \text { to } 10 \text {. Lower scores indicate lower quality. }\end{array}$ \\
\hline Corruption & $\begin{array}{l}\text { Assessment of the corruption in government. Lower scores indicate that ranking government officials } \\
\text { are likely to demand bribes and that these illegal payments are generally expected in lower levels of } \\
\text { government in the form of bribes for import and export licenses, policy protection, exchange controls, } \\
\text { tax assessment, or loans." Scaled from zero to 10, with lower scores for higher levels of corruption. } \\
\text { Source: La Porta et al., } 1998 \text {. }\end{array}$ \\
\hline $\begin{array}{l}\text { Risk of Contract } \\
\text { Repudiation }\end{array}$ & $\begin{array}{l}\text { This index is an assessment of the risk that a contract will be modified through a repudiation, } \\
\text { postponement, or scaling down due to various conditions, including a change in government, budget } \\
\text { cutbacks, indigenization pressure, or a change in government economic and social priorities. Scaled } \\
\text { from zero to 10, with lower scores for higher risks. Source: La Porta, et al., } 1998 \text {. }\end{array}$ \\
\hline Primary religion & $\begin{array}{l}\text { Identifies the highest percentage of the population of each country that belongs to one of the three } \\
\text { religions: (1) Roman catholic; (2) Protestant; (3) Muslim. Source: La Porta et al., } 1999\end{array}$ \\
\hline Primary language & Identifies the primary official language of a country. Source: Stulz and Williamson, 2003. \\
\hline $\begin{array}{l}\text { Private Credit by } \\
\text { Deposit Money } \\
\text { Banks and Other } \\
\text { Financial } \\
\text { Institutions to GDP }\end{array}$ & $\begin{array}{l}\text { This variable is calculated using the following deflation method: } \\
(0.5) \times\left[\left(F_{t} / P_{e_{t}}+F_{t-1} / P_{e_{t-1}}\right) /\left(G D P_{t} / P_{a_{t}}\right)\right] \text {, where } \mathrm{F} \text { is credit to the private sector, } P_{e} \text { is end-of } \\
\text { period CPI, and } P_{a} \text { is average annual CPI. It captures the financial intermediation with the private } \\
\text { nonfinancial sector. Source: The IMF }\end{array}$ \\
\hline $\begin{array}{l}\text { Cost of } \\
\text { Bankruptcy } \\
\text { Procedure } \\
\end{array}$ & $\begin{array}{l}\text { Measures the cost involved in filing bankruptcy as a percentage of the assets of the firm filing for } \\
\text { bankruptcy. Rescaled to } 0 \text { to } 10 \text { from previous scale of } 0 \text { to } 100 \text {; with higher score indicating higher cost } \\
\text { of filing for bankruptcy. Source: Peng, Yamakawa, \& Lee, 2009 }\end{array}$ \\
\hline GDP Growth & $\begin{array}{l}\text { Measures the real GDP (annual percentage change) of each country. Source: International Monetary } \\
\text { Fund. }\end{array}$ \\
\hline Uner & our Organ \\
\hline
\end{tabular}

This table describes the variables, the source of all the variables used in the analysis and the total number of observations.

The third section of Table 2 describes the legal, government, culture, and economic control variables. Klapper et al. (2008) illustrates that legal environment is important for new firm creation. La Porta et al. (1999) finds that a country's legal origin is important for many economic aspects. To capture the efficiency of the legal system, we construct the Legal System composite index by combining together the Efficiency of Judicial System, Rule of Law, Creditor Rights, Eviction Procedures and Check Collection variables. First, we rescale all the variables between 0 and 10. Then we compute an average to form our legal System composite index. Lower scores indicate lower quality. The specific indices in our composite index include two measures that relate to the enforcement of the judicial system and three indexes that measure the level of legal protection in favor of managers. These manager oriented indexes include the credit rights index (Djankov et al, 2007), which measures the legal rights of creditors against defaulting debtors in different jurisdictions. Qi et al. (2011) shows that stronger credit rights compared to shareholder rights substitute for bond covenant restrictions. The procedure formalism index (Djankov et al., 2003) measures the procedural formalism for resolving disputes. This index has two sub-indexes; the eviction procedure index and the 
collection of checks index. These indexes measure the procedures used by litigants and courts to evict a tenant for nonpayment of rent and to collect a bounced check. By evaluating the way that courts in different countries solve these simple disputes, these indexes measure the effectiveness of courts in different legal systems.

La Porta et al., 1998, examines two different quality of government proxies: corruption and risk of contract repudiation. These measures are compiled by private credit risk agencies for the use of foreign investors interested in doing business in the respective countries. We combine these two proxies together into a Government Efficiency Index. To do this, we repeat the same procedure used for the Legal System Index using the Corruption and Risk of Contract Repudiation variables.

We also control for the effect of culture on firm births. Although a government can change its business regulations and policies, it is unlikely to be able to change its culture. Nevertheless, culture seems to impact business activity (Guiso, Sapienza, \& Zingales, 2006). Audretsch et al. (2007) find in India, one's religious affiliation does impact the propensity for entrepreneurship activity. Islam and Christianity were found to be conducive to entrepreneurship, while Hinduism inhibited entrepreneurship. To study the effect of culture, we consider the religion (La Porta et al., 1999) and language (Stulz \& Williamson, 2003) for each country. The primary religion (language) is defined as the one practiced (spoken) by the largest fraction of the population of a country. Of the 19 countries, 10 countries have Roman Catholic religion as their primary religion and the remaining 9 countries are Protestant countries. Therefore, the analysis about religion only shows us the effect of the Roman Catholic and Protestant religion on the birth of new businesses, but we cannot derive a conclusion about the impact of other religions. In addition, since our dataset has 12 different languages we only run our tests for Dutch, English, German, and Scandinavian. (Note 2) The rest of the languages are grouped together as a variable named "Other." These independent variables for each country are reported in Table 3.

Lastly, we also include economic control variables in our analysis. Aghion, Fally and Scarpetta (2007) examine the effects of financial development of a country on the entry of new firms using private credit as one of the proxies for the degree of financial development. They conclude that private credit is important for promoting entry of new firms. Following Aghion et al., 2007, we include a private credit variable from the IMF International Financial Statistics database. This variable includes claims by both deposit money banks and other financial institutions. It measures the credit issued to the private sector as opposed to credit issued to governments and public enterprises. In other words, it measures the activity of financial intermediaries in channeling savings to investors and businesses. Deposit money banks and other financial institutions are bigger and more active in richer countries, whereas central banks are smaller.

Table 3. Legal System, Business Environment and Cultural Variables

\begin{tabular}{|c|c|c|c|c|c|c|c|c|c|c|c|c|}
\hline Country & $\begin{array}{l}\text { Regulation } \\
\text { of Entry }\end{array}$ & $\begin{array}{l}\text { Employment } \\
\text { laws index }\end{array}$ & $\begin{array}{l}\text { Collective } \\
\text { Relations } \\
\text { index }\end{array}$ & $\begin{array}{c}\text { Social } \\
\text { Security } \\
\text { laws index }\end{array}$ & $\begin{array}{l}\text { Accounting } \\
\text { Standards }\end{array}$ & $\begin{array}{l}\text { Corporate } \\
\text { Tax Rate }\end{array}$ & $\begin{array}{l}\text { Legal } \\
\text { System } \\
\text { Index }\end{array}$ & $\begin{array}{l}\text { Government } \\
\text { Efficiency } \\
\text { Index }\end{array}$ & $\begin{array}{c}\text { Cost of } \\
\text { Bankruptcy }\end{array}$ & Legal Origin & Language & Religion \\
\hline Australia & 9 & 0.3515 & 0.3720 & 0.7820 & 75 & 30.00 & 6.58 & 8.62 & 8 & English & English & Catholic \\
\hline Austria & 25 & 0.5007 & 0.3601 & 0.7139 & 54 & 34.00 & 6.14 & 9.09 & 18 & German & German & Catholic \\
\hline Belgium & 19 & 0.5133 & 0.4226 & 0.6240 & 61 & 33.99 & 6.58 & 9.15 & 4 & French & Dutch & Catholic \\
\hline Canada & 7 & 0.2615 & 0.1964 & 0.7869 & 74 & 36.12 & 5.61 & 9.48 & 4 & English & English & Catholic \\
\hline Denmark & 5 & 0.5727 & 0.4196 & 0.8727 & 62 & 30.00 & 7.26 & 9.66 & 9 & Scandinav & Danish & Protestant \\
\hline Finland & 13 & 0.7366 & 0.3185 & 0.7863 & 77 & 29.00 & 6.12 & 9.58 & 4 & Scandinav & Finnish & Protestant \\
\hline France & 31 & 0.7443 & 0.6667 & 0.7838 & 69 & 35.43 & 5.35 & 9.12 & 9 & French & French & Catholic \\
\hline Germany & 20 & 0.7015 & 0.6071 & 0.6702 & 63 & 37.07 & 7.22 & 9.35 & 8 & German & German & Protestant \\
\hline Italy & 53 & 0.6499 & 0.6310 & 0.7572 & 62 & 37.25 & 6.38 & 7.65 & 22 & French & Italian & Catholic \\
\hline Japan & 12 & 0.1639 & 0.6280 & 0.6417 & 65 & 42.05 & 6.71 & 9.11 & 4 & German & Japanese & Protestant \\
\hline Netherlands & 21 & 0.7256 & 0.4643 & 0.6268 & 64 & 34.50 & 7.23 & 9.68 & 1 & French & Dutch & Catholic \\
\hline New Zealand & 2 & 0.1607 & 0.2500 & 0.7188 & 70 & 33.00 & 6.81 & 9.65 & 4 & English & English & Protestant \\
\hline Norway & 11 & 0.6853 & 0.6488 & 0.8259 & 74 & 28.00 & 6.90 & 9.86 & 1 & Scandinav & Norwegian & Protestant \\
\hline Portugal & 37 & 0.8088 & 0.6488 & 0.7352 & 36 & 27.50 & 5.76 & 1.96 & 9 & French & Portuguese & Catholic \\
\hline Spain & 38 & 0.7447 & 0.5863 & 0.7660 & 64 & 35.00 & 6.68 & 7.89 & 14 & French & Spanish & Catholic \\
\hline Sweden & 14 & 0.7405 & 0.5387 & 0.8448 & 74 & 28.00 & 6.30 & 9.72 & 9 & Scandinav & Swedish & Protestant \\
\hline Switzerland & 16 & 0.4520 & 0.4267 & 0.8151 & 68 & 24.10 & 4.47 & 9.99 & 4 & German & German & Catholic \\
\hline U. K. & 6 & 0.2824 & 0.1875 & 0.6915 & 78 & 30.00 & 7.09 & 9.37 & 6 & English & English & Protestant \\
\hline USA & 3 & 0.2176 & 0.2589 & 0.6461 & 71 & 45.20 & 6.10 & 8.82 & 7 & English & English & Protestant \\
\hline
\end{tabular}

This table reports the values of legal system, business environment, and cultural variables by country. 
We also account for the state of the economy of each country by including the gross domestic product (GDP) annual percentage change and the unemployment rate. The GDP data are from the International Monetary Fund and the unemployment data are from LABORSTA. The mean for the GDP growth varies from $-4.28 \%$ for the year 2009 to $4.02 \%$ for the year 2000 (Table 1), while the mean for the unemployment rate varies from $5.20 \%$ for the year 1995 to $8.84 \%$ for the year 1997 . The standard deviation for both control variables shows a big variation in both the GDP growth and unemployment rates.

In the firm death rate analysis we consider an additional economic control variable, the cost of bankruptcy variable. Peng et al. (2010) concludes that the cost spent on the bankruptcy procedure has a significant effect on the number of businesses filing for bankruptcy in a country. As the cost of bankruptcy increases it provides incentives for firms to delay filing for bankruptcy.

\section{Firm Birth Rate Analysis}

We examine firm birth rates and sets of variables describing business policy, the legal system, quality of government, and culture. We first explore the control variables and firm birth rates and follow with our multivariate regressions.

\subsection{Control Variable Analysis}

Our legal, government, and culture control variables are explored in Table 4. There is a great deal of evidence suggesting that legal origins affect the business activity of a country. Legal origin has a substantial impact on important economic outcomes; like financial development, unemployment, corporate governance, investment, entry, the size of the unofficial economy, and international trade (La Porta, López-de-Silanes, \& Shleifer, 2008; Kim et al., 2007). We analyze whether the legal system has a direct effect on business creation. Table 4, Panel A, reports the univariate test results for the four (Note 3) legal system origins and the legal protection indexes. The mean birth rates are shown in the legal systems origins and compared using an F-test. We find that English and German legal systems have the highest birth rates, followed by the French and the countries with Scandinavian legal origins. The reported F-test value of 7.36 indicates that the legal systems birth rate means are not equal to each other, significant at the 1 percent level. Countries with English legal origin have a higher rate of new business births than the countries with French legal origin. This result is consistent with La Porta at al. (1999), which concludes that common law countries have better governments than French civil law or socialist law countries. Common law, compared to French civil law, is associated with better investor protection, which in turn is associated with improved financial development, higher ownership dispersion, less corruption, better functioning labor markets, and less formalized and more independent judicial systems.

Correlations are also reported for the legal system indexes and the birth rates in Panel A. The indexes measuring the efficiency of the judicial system and rule of law are not correlated with birth rates. The efficiency of the judicial system is a measure designed for foreign investors, thus it might not impact domestic entrepreneurs as much. The positive correlation for Credit Rights is consistent with the hypothesis that a stronger legal system for credit providers fosters new firm births. The indexes measuring eviction procedures and the collection of checks are negatively correlated with firm birth rates. Both of these indexes correlations with birth rate are significant at the five percent level. These are both lower court measures that indicate higher judicial intervention in these processes. Lower intervention fosters more firm births. The combination legal index, Legal System Index, shows a positive, but insignificant correlation.

Panel B of Table 4 analyzes the univariate relation between the firm birth rate and the quality of government variables (corruption and repudiation risk). Note that for these variables, a higher number means less corruption and risk. The correlation between Corruption and firm birth rates indicate that higher quality government fosters a higher birth rate. Repudiation Risk is not significant. The Government Efficiency Index, which is a combination of the two, has an insignificant positive correlation with firm birth rate.

Table 4. Firm Birth Rates and Control Variables

Panel A: Legal System Variables

\begin{tabular}{|c|c|c|c|c|c|}
\hline \multicolumn{6}{|c|}{ Mean Birth Rates of Legal Origin } \\
\hline English & French & German & Scandinavian & \multicolumn{2}{|l|}{ F-test } \\
\hline $0.119 * * *$ & $0.093 * * *$ & $0.099 * * *$ & $0.091 * * *$ & \multicolumn{2}{|l|}{$7.36^{* * *}$} \\
\hline \multicolumn{6}{|c|}{ Correlation between Legal System Variables and Birth Rates } \\
\hline $\begin{array}{l}\text { Efficiency of } \\
\text { Judicial System }\end{array}$ & Rule of Law & $\begin{array}{l}\text { Eviction } \\
\text { Procedures }\end{array}$ & $\begin{array}{l}\text { Collection } \\
\text { Checks }\end{array}$ & $\begin{array}{l}\text { Credit } \\
\text { Rights }\end{array}$ & $\begin{array}{ll}\text { Legal } & \text { System } \\
\text { Index } & \end{array}$ \\
\hline 0.009 & -0.056 & $-0.219 * *$ & $-0.160^{* *}$ & $0.434 * * *$ & 0.263 \\
\hline
\end{tabular}


Panel B: Correlation between Quality of Government Variables and Birth Rates

\begin{tabular}{ll|l}
\hline Corruption & $\begin{array}{l}\text { Repudiation } \\
\text { Risk }\end{array}$ & $\begin{array}{l}\text { Government } \\
\text { Efficiency Index }\end{array}$ \\
\hline $0.126^{*}$ & -0.029 & 0.092 \\
\hline
\end{tabular}

Panel C: Mean Birth Rates for Culture Variables

\begin{tabular}{llllll}
\hline $\begin{array}{l}\text { Language } \\
\text { Dutch }\end{array}$ & English & German & Scandinavian & Other & F-test \\
\hline $0.085 * * *$ & $0.120 * * *$ & $0.107 * * *$ & $0.091 * * *$ & $0.092 * * *$ & $7.28 * * *$ \\
\hline $\begin{array}{l}\text { Religion } \\
\text { Catholic }\end{array}$ & Protestant & & & F-test \\
\hline $0.091 * * *$ & $0.107 * * *$ & & & $12.84 * * *$ \\
\hline
\end{tabular}

Panel A of this table reports univariate analysis of the legal variables. The first part shows the mean birth rate in each legal origin and an F-statistic testing whether these means are equal. The second part shows the correlation between each legal system index and the birth rate. Panel B of this table reports the correlations between the quality of government indexes and the birth rates. Panel $\mathrm{C}$ of this table reports mean birth rates in different language and religion regions. An F-statistic tests whether the mean estimates are equal. Note: Scandinavian (=Swedish, Finnish, Danish, and Norwegian) $* * *$ indicates significance at the $1 \%$ level, ** 5\% level, * 10\% level.

We show the relation between culture and firm birth rate in Panel $\mathrm{C}$. We consider language and religion as a representation of the culture of each country (Stulz \& Williamson, 2003). We consider only Dutch, English, German, and Scandinavian languages and group the rest of the languages in a variable called "Other." The mean birth rates in each language and religion is shown. The $F$-test value of 7.28 is large, implying that the language has an effect on the birth rate of each country. The means vary from 0.085 for the Dutch language to 0.120 for the English speaking countries. The countries with the highest proportion of Protestants have a higher mean birth rate than the Catholic countries, and the $F$-test of 12.84 is significantly large in testing for the difference between these two religions.

\subsection{Regression Analysis}

Since our dependent variable data are proportional data, we use a logit transformation (Note 4) on the firm birth rate (see Papke \& Wooldridge, 1996) for regression analysis. Specifically we run all our regressions with the logit firm birth rate as the dependent variable. We use a panel dataset and thus need to choose an econometric model. The fixed effects and random effects are two common choices. We have five variables that are perfectly collinear with the fixed effects; Legal Index, Government Index, Easy of Doing Business (Entry) Employment Index and Social Security Index. For each country, these variables do not change through time. This leads us to choose the random effects model. This choice is confirmed using the Hausman test. This test compares the more efficient random effects model against the less efficient but consistent fixed effects model. (Note 5) In addition, we also employ a second model, the population-averaged Generalized Estimating Equations (GEE).

We analyze the firm birth rate using all of the policy and control variables. However, several of the control variables are highly correlated. Thus, we run one regression using English and German Law dummy variables and a Catholic variable. Then we replace those variables with Language variables and the Protestant variable. Table 5 shows the estimation results. In the first regression we use the English Law, German Law, and Catholic dummy variables. The random effects model estimates for the policy variables show that the Regulation of Entry and variables have a significantly positive coefficient and Accounting Quality has a significantly negative coefficient. Regulation of Entry, the one index targeted directly to small firms, has a statistically significant coefficient. Higher social security benefits reduce the risk for entrepreneurs' retirement income and thus foster new firm creation. The positive, but insignificant, coefficients of the Employment Law and Collective Relations Indexes indicates that more burdensome employment laws and higher protection of labor unions could lead to higher new firm creation. New small firms are unlikely to have to deal with labor unions and thus may have the advantage over large firms. Lastly, although higher accounting standards make businesses more transparent for investors, they also may be a hurdle for entrepreneurs creating businesses. The negative estimate makes sense because large firms have the resources to better deal with sophisticated accounting practices than small firms, and thus have a competitive advantage over new firms.

All of the legal and government control variables have significantly positive coefficients, except for German, which is insignificantly negative. The Catholic religion and the Private Credit are both significantly negative, while English 
Law and the Protestant religion are associated with higher firm birth rates. Also, it appears that a high unemployment rate motivates people to start their own business, especially during high economic growth periods. The GEE model estimates show similar results with the random effects model.

Table 5. Determinants of Firm Birth Rates

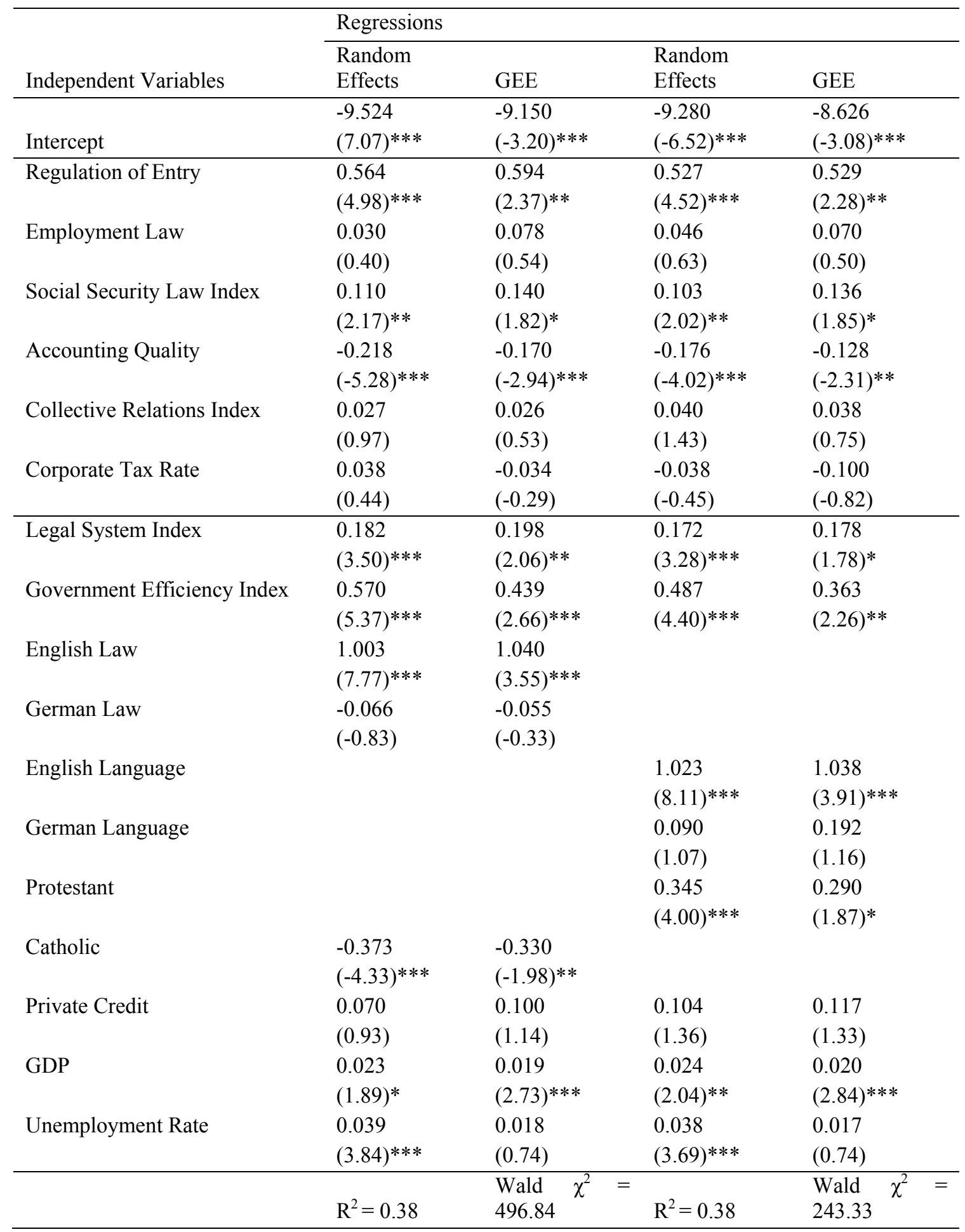

This table reports the Random Effect and GEE Model estimates of regressions of the logit transformation of the firm birth rate with the business policy variables and the control variables. $z$-statistics are reported in parentheses. $\mathrm{N}=165$. $* * *$ indicates significance at the $1 \%$ level, ** $5 \%$ level, * $10 \%$ level. 


\section{Firm Death Rates}

Very few studies examine firms ceasing operations. Note that birth rates and death rates are fundamentally different. New firms are generally small. Firms ceasing operations are more likely to be of any size. We proceed from the perspective that policies, legal systems, government quality and culture that inhibit big business, and thus spur new firm births, might go so far and drive existing firms out of business. Therefore, we expect to see the same sign on the explanatory variables explaining death rates as seen on the birth rates. We explore death rates by repeating the regression equations of Table 5 for firm death rates. We have a total of 157 observations covering the period from year 1995 to 2011. The descriptive statistics of firm death rates are reported in Table 1. The means and standard deviations of the death rates are usually smaller than those of the birth rates are, for every year. This implies that there is a higher rate of new business startup than the rate of firms that cease business. However, it can be argued that countries with a high firm birth rate will be more likely to have a high firm death rate because there are more young firms. Therefore, we control for birth rate in the death rate regression by adding the variable $\ln ($ birth rate). Similar to the birth rate analysis, we specify the dependent variable as the logit transformation of the death rate.

The results are shown in Table 6. Higher birth rates are associated with higher death rates. For the policy variables, the coefficients are generally of the same sign as estimated for the firm birth rates. For example, Regulation of Entry, Employment Law, and Social Security Laws have significantly positive coefficients, similar to the birth rate analysis. Also, higher accounting standards are associated with lower firm deaths. The policy variable that shows a difference between the birth and death rate regressions is the Collective Relations Index. The collective relation variable was insignificant and positive in the birth rate analysis. For the death rate analysis, it is negative and significant in one of the four regressions. This suggests that higher labor union protections reduce death rates. As for the control variables, the Government Efficiency Index is associated with higher death rates. English Law, German Law, and Protestant indicators are also associated with higher death rates. The negative coefficient on the Catholic estimate suggests that those countries have a lower firm death rate. We added an additional control variable for the death rate analysis to account for the cost of bankruptcy. The coefficient is not significant. A higher unemployment rate is associated with more firm deaths. 
Table 6. Firm Death Rate Analysis

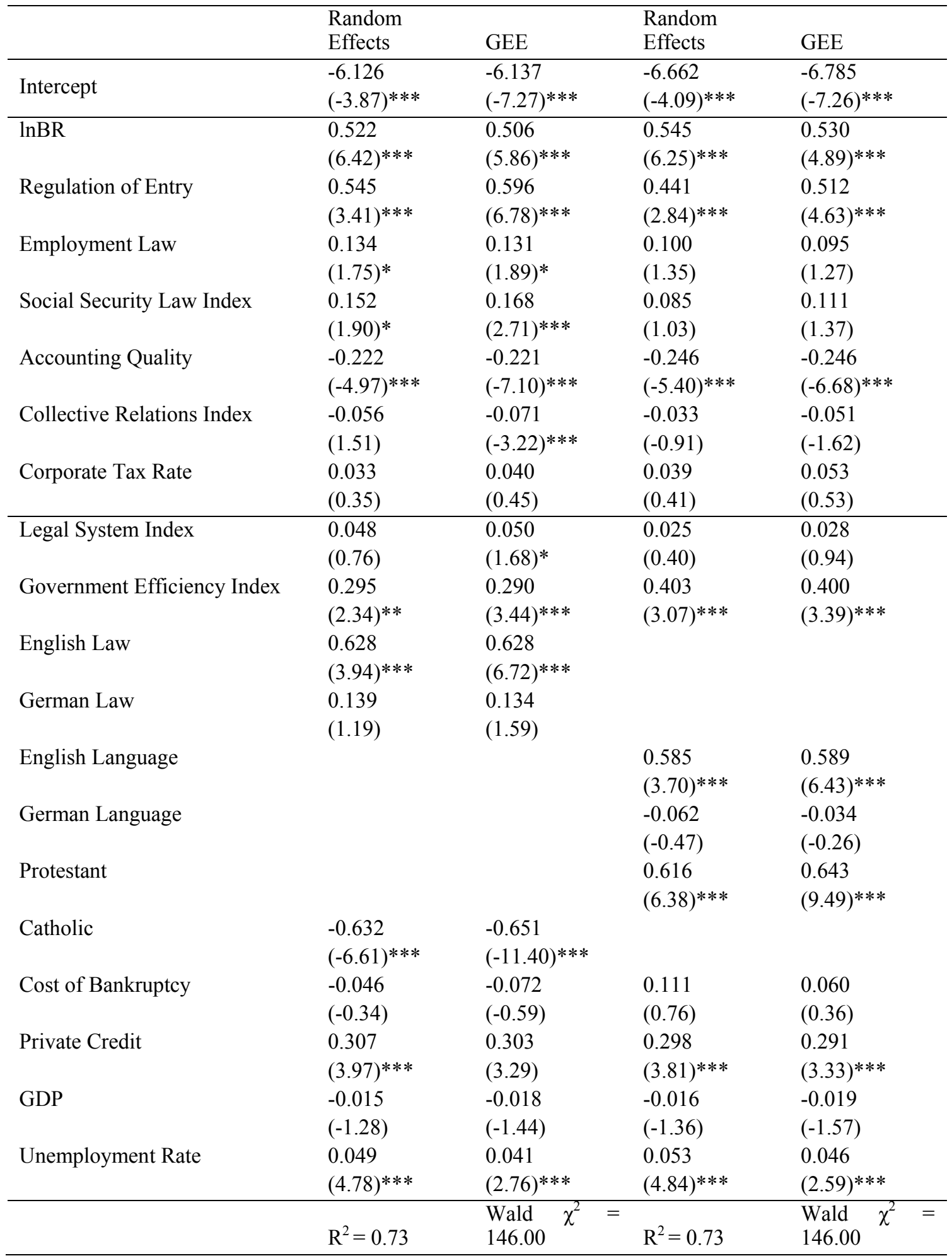

This table reports the Random Effect and GEE Model estimates of regressions of the logit transformation of the death rate with the business policy variables and the control variables. $z$-statistics are reported in parentheses. $\mathrm{N}=140$. $* * *$ indicates significance at the $1 \%$ level, $* * 5 \%$ level, * $10 \%$ level. 


\section{Conclusions}

Most business policies and laws are enacted to support big business or to protect employees. Burdensome policies to large companies may give new, small firms that are exempt from those regulations a competitive advantage. Thus, we examine the business policies that a government employs on the rate new firms are created and the number of firms that cease operating. We find that countries with tough employment, social security, and labor laws create inefficiencies at large firms such that it fosters more new firm creation. On the other hand, higher accounting standards require specialized accounting skills that are more likely to be found in large firms. Consistent with the idea that large firms have the comparative advantage for accounting functions, we find that higher accounting standards are negatively associated with the startup of new firms.

Countries with better government efficiency (low degrees of corruption or repudiation risk) and legal system are associated with higher firm birth rate. The English legal origin is associated with a high degree of firm birth rates. Culture variables like language and religion also have explanatory power in explaining firm birth rates. English speaking countries and countries with a majority of Protestant religion followers have higher firm startups. Countries with the highest percentage of the Catholics have a negative relation with the firm birth rate.

Business policies that are burdensome to large companies create opportunities for new small businesses. However, the burden can lead more existing firms to fail. Thus, having strong protections for employees may strain large firms and lead to more firm births. These strained firms may fail, causing higher firm deaths. Indeed, we find that most of our explanatory variables for firm birth rates appear to have the same sign in the death rate regressions.

\section{Acknowledgements}

We thank Douglas Cumming, Alicia Robb, and participants at York University, the University of Vlora, and the Academy of Entrepreneurial Finance conference for providing feedback.

\section{References}

Aghion, P., Fally, T., \& Scarpetta, S. (2007). Credit constraints as a barrier to the entry and post-entry growth of firms. Economic Policy, 22(52), 731-779. http://dx.doi.org/10.1111/j.1468-0327.2007.00190.x

Anyadike-Danes, M., Hart, M., \& O'Reilly, M. (2005). Watch that space! The county hierarchy in firm births and deaths in the UK, 1980-1999. Small Business Economics, 25(3), 273-292. http://dx.doi.org/10.1007/s11187-004-3681-6

Armour, J., \& Cumming, D. J. (2006). The legal road to replicating Silicon Valley. Oxford Economic Papers, 58(4), 596-635. http://dx.doi.org/10.1093/oep/gp1007

Audretsch, D. B., Boente, W., \& Tamvada, J. P. (2007). Religion and entrepreneurship. JENA Economic Research Paper, 2007-075.

Beck, T., Demirgüç, A., \& Maksimovic, V. (2005). Financial and legal constraints to growth: Does firm size matter? The Journal of Finance, 60(1), 137-177. http://dx.doi.org/10.1111/j.1540-6261.2005.00727.x

Botero, J.C., Djankov, S., La Porta, R., López-de-Silanes, F., \& Shleifer, A. (2004). The regulation of labor. The Quarterly Journal of Economics, 119(4), 1339-1382. http://dx.doi.org/10.1162/0033553042476215

Claessens, S., \& Laeven, L. (2003). Financial development, property rights, and growth. Journal of Finance, 58(6), 2401-2436. http://dx.doi.org/10.1046/j.1540-6261.2003.00610.x

Demirguc-Kunt, A., Klapper, L. F., \& Panols, G. A. (2013). Entrepreneurial finance in the Western Balkans: Characteristics of the newly self-employed in Albanaia, Bosnia and Herzegovina, and Serbia. In R. Kull, A. Demirguc-Kunt, \& R. Morduch (Eds.), Banking the World: Empirical Foundations of Financial Inclusion, 211-264.

Djankov, S., La Porta, R., López-de-Silanes, F., \& Shleifer, A. (2002). The regulation of entry. The Quarterly Journal of Economics, 117(1), 1-37. http://dx.doi.org/10.1162/003355302753399436

Djankov, S., La Porta, R., López-de-Silanes, F., \& Shleifer, A. (2003). Courts. The Quarterly Journal of Economics, 118(2), 453-517. http://dx.doi.org/10.1162/003355303321675437

Djankov, S., McLiesh, C. \& Shleifer, A. (2007). Private credit in 129 countries. Journal of Financial Economics, 84(2), 299-329. http://dx.doi.org/10.1016/j.jfineco.2006.03.004

Djankov, S., Ganser, T. McLiesh, C., Ramalho, R., \& Shleifer, A. (2008). The law and economics of self-dealing. Journal of Financial Economics, 88(3), 430-465. http://dx.doi.org/10.1016/j.jfineco.2007.02.007 
Djankov, S., Ganser, T. McLiesh, C., Ramalho, R., \& Shleifer, A. (2010). The effect of corporate taxes on investment and entrepreneurship. American Economic Journal: Macroeconomics, American Economic Association, 2, 31-64. http://dx.doi.org/10.1257/mac.2.3.31

Eurostat. (2004). Preliminary Entrepreneurship Indicators Programme (EIP) Data. Eurostat Website.

Foster, L., Haltiwanger, J. \& Krizan, C. J. (2006). Market selection, reallocation, and restructuring in the U.S. retail trade sector in the 1990s. Review of Economics and Statistics, 88(4), 748-758. http://dx.doi.org/10.1162/rest.88.4.748

Fritsch, M. (2008). How does new business formation affect regional development? Small Business Economics, 30(1), 1-14. http://dx.doi.org/10.1007/s11187-007-9057-y

Guasch, J. L., \& Hahn, R. W. (1999). The costs and benefits of regulations: Some implications for developing countries. The World Bank Research Observer, 14(1), 137-58. http://dx.doi.org/10.1093/wbro/14.1.137

Guiso, L., Sapienza, P., \& Zingales, L. (2006). Does culture affect economic outcomes? Journal of Economic Perspectives, 20(2), 23-48. http://dx.doi.org/10.1257/jep.20.2.23

International Monetary Fund. (2005). World economic outlook, 2005.

Johnson, S., McMillan, J., \& Woodruff, C. (2002). Property rights and finance. American Economic Review, 92(5), 1335-1356. http://dx.doi.org/10.1257/000282802762024539

Kim, K. A., Ketsabunnarat-Chatjuthamard, P., \& Nofsinger, J. R. (2007). Large shareholders, board independence, and minority shareholder rights: Evidence from Europe. Journal of Corporate Finance, 13(5), 859-880. http://dx.doi.org/10.1016/j.jcorpfin.2007.09.001

Klapper, L., Amit, R., Guillén, M. F., \& Quesada, J. M. (2008). Entrepreneurship and firm formation across countries. In J. Lerner and A. Shoar (Eds.), NBER Volume on International Differences in Entrepreneurship, University of Chicago Press. http://dx.doi.org/10.1596/1813-9450-4313

Klapper, L., Laeven, L, \& Rajan, R. (2006). Entry regulation as a barrier to entrepreneurship. Journal of Financial Economics, 82(3), 591-629. http://dx.doi.org/10.1016/j.jfineco.2005.09.006

Klapper, L., Love, I., \& Randall, D. (2014). New firm registration and the business cycle. World Bank Policy Research Working Paper 6775.

LABORSTA. (2007). LABORSTA Labour Statistics Database. International Labour Organization (ILO), Geneva.

La Porta, R., López-de-Silanes, F., Shleifer, A., \& Vishny, R. (1997). Legal determinants of external finance. Journal of Finance, 52(3), 1131-1150. http://dx.doi.org/10.1111/j.1540-6261.1997.tb02727.x

La Porta, R., López-de-Silanes, F., Shleifer, A., \& Vishny, R. (1998). Law and finance. Journal of Political Economy, 106(6), 1113-1155. http://dx.doi.org/10.1086/250042

La Porta, R., López-de-Silanes, F., Shleifer, A., \& Vishny, R. (1999). The quality of government. Journal of Law, Economics and Organization, 15(1), 222-279. http://dx.doi.org/10.1093/jleo/15.1.222

La Porta, R., López-de-Silanes, F., Shleifer, A., \& Vishny, R. (2000). Investor protection and corporate governance. Journal of Financial Economics, 58(1-2), 3-27. http://dx.doi.org/10.1016/S0304-405X(00)00065-9

La Porta, R., López-de-Silanes, F., \& Shleifer, A., (2008). The economic consequences of legal origins. Journal of Economic Literature, 46(2), 285-332. http://dx.doi.org/10.1257/jel.46.2.285

Lowe, R. A., \& Ziedonis, A. A. (2006). Over-optimism and the performance of entrepreneurial firms. Management Science, 52(2), 173-186. http://dx.doi.org/10.1287/mnsc.1050.0482

Nofsinger, J R. (2012). Household behavior and boom/bust cycles. Journal of Financial Stability, 8(3), 161-173. http://dx.doi.org/10.1016/j.jfs.2011.05.004

Nofsinger, J. R., \& Wang, W. (2011). Determinants of start-up firm external financing worldwide. Journal of Banking and Finance, 35(9), 2282-2294. http://dx.doi.org/10.1016/j.jbankfin.2011.01.024

OECD. (2007). OECD.StatExtract ILibrary. December. OECD / Eurostat Business Demography Database.

Papke, L., \& Wooldridge, J. (1996). Econometric methods for fractional response variables with an application to 401(k) plan participation rates. Journal of Applied Econometrics, 11(6), 619-632. http://dx.doi.org/10.1002/(SICI)1099-1255(199611)11:6\%3C619::AID-JAE418\%3E3.0.CO;2-1 
Peng, M. W., Yamakawa, Y., \& Lee, S. H. (2010). Bankruptcy laws and entrepreneur-friendliness. Entrepreneurship Theory and Practice, 34(3), 517-530. http://dx.doi.org/10.1111/j.1540-6520.2009.00350.x

Praag, C. M., \& Verslott, P. H. (2007). What is the value of entrepreneurship? A review of recent research. Small Business Economics, 29(4), 351-382. http://dx.doi.org/10.1007/s11187-007-9074-x

Qi, Y., Roth, L., \& Wald, J. K. (2011). How legal environments affect the use of bond covenants. Journal of International Business Studies, 42(2), 235-262. http://dx.doi.org/10.1057/jibs.2010.52

Rajan, R., \& .Zingales, L. (2003). The great reversal: The politics of financial development in the $20^{\text {th }}$ century. Journal of Financial Economics, 69(1), 5-50. http://dx.doi.org/10.1016/S0304-405X(03)00125-9

Reynolds, P. D., Miller, B., \& Maki, W. R. (1995). Explaining regional variation in business births and deaths: U.S. 1976-88. Small Business Economics, 7(5), 389-408. http://dx.doi.org/10.1007/BF01302739

Santarelli, E., \& Piergiovanni, R. (1995). The determinants of firm start-up and entry in Italian producer services. Small Business Economics, 7(3), 221-230. http://dx.doi.org/10.1007/BF01135367

Stulz, R. M., \& Williamson, R. (2003). Culture, openness and finance. Journal of Financial Economics, 70(3), 313-349. http://dx.doi.org/10.1016/S0304-405X(03)00173-9

Wong, P. K., Ho, Y. P., \& Autio, E. (2005). Entrepreneurship, innovation and economic growth: Evidence from GEM data. Small Business Economics, 24(3), 335-350. http://dx.doi.org/10.1007/s11187-005-2000-1

The World Bank. (2007). The doing business project. The World Bank Group and the International Finance Corporation.

The World Bank. (2007). Financial structure database. The World Bank Group.

Zucker, L. G., Darby, M. R., \& Brewer, M. B. (1998). Intellectual human capital and the birth of U.S. biotechnology enterprises. American Economic Review, 88(1), 290-306. http://www.jstor.org/stable/116831

\section{Notes}

Note 1 . Of the 195 total observations, 179 have birth rate data and 157 have death rate data.

Note 2. The Scandinavian language variables include Swedish, Finish, Danish and Norwegian.

Note 3. We have no countries with a Socialist legal Origin. Our data includes countries with English, French, German or Scandinavian legal origin.

Note 4. We transform the firm birth rate into $\ln \left(\frac{\text { Firm Birth Rate }}{1-\text { Firm Birth Rate }}\right)$.

Note 5. Our Hausman test result is $\chi^{2}=0.02$ and Prob $>\chi^{2}=1.000$. We fail to reject the Null hypothesis. 